\title{
ON THE BRANCH DEVELOPMENT IN LEUCODON (LEUCODONTACEAE, BRYOPHYTA)
}

\author{
О РАЗВИТИИ ВЕТОЧЕК У LEUСОDОN \\ (LEUCODONTACEAE, BRYOPHYTA)
}

\author{
ULIANA N. SPIRINA ${ }^{1} \&$ MICHAEL S. IGNATOV ${ }^{2}$ \\ УЛЬЯНА Н. СПИРИНА ${ }^{1}$, МИХАИЛ С. ИГНАТОВ 2
}

\begin{abstract}
Branch primordia of Leucodon and Pterogoniadelphus are studied, and their structure is found to be very similar to that of Brachytheciaceae and Meteoriaceae. The first branch leaf points downwards, although the first division of the branch initial cell cuts off the first merophyte in the "four o'clock" position, i.e. in the same way as in other mosses. One difference from Brachytheciaceae is that the first branch leaf is often split into a number of lobes in some species, including the widespread Leucodon sciuroides, obscuring the specific position of this leaf. Possible reasons of this anomalous pattern are discussed.
\end{abstract}

Резюме

Изучены ранние стадии развития веточек родов Leucodon и Pterogoniadelphus, у которых выявлен аномальный тип, ранее известный только у Brachytheciaceae и Meteoriaceae. Первый развитый лист располагается выше зачатка веточки по стеблю и обращен своей верхушкой к основанию стебля. При этом, однако, первые мерофиты отделяются от инициальной клетки веточки в обычной для мхов последовательности, при которой первый из них оказывается в положении "4 часа". В отличие от Brachytheciaceae, y Leucodon первый веточный лист часто разделен на две или большее количество долей, что затрудняет интерпретацию наблюдаемой картины развития. Обсуждаются возможные причины аномального развития в этих группах, которые, вероятно, обусловлены сходством условий обитания.

KEYWORDS: anatomy, branching, Bryophyta, development, Leucodon, systematics

\section{INTRODUCTION}

The present paper continues our study on the structure and development of branch primordia in pleurocarpous mosses, which appears to be valuable for systematics, especially in Brachytheciaceae and Meteoriaceae, where the first branch leaf ('pseudoparaphyllium') is pointed downwards (Ignatov, 1999), contrary to the most common pattern where the first branch leaf is lateral, designated by Ignatov \& Hedenäs (2007) as the "four o'clock" position.
Providing a list of pleurocarpous moss species with and without 'Brachytheciaceae-Meteoriaceae' pattern, Ignatov (1.c.) did not mention Leucodon, as previous observations on Leucodon sciuroides with light microscopy provided controversial results. Some buds looked having the first branch leaf in a position similar to Brachytheciaceae, while others had leafy structures in upper-lateral position, and rarely in a "four o'clock" position. Thus the case of Leucodon is investigated in detail here.

1 - Biological Faculty, Tver State University, Zhelyabova 33, Tver 170000 Russia - Россия 170000 Тверь, Желябова, 33, Тверской государственный университет, Биологический факультет; e-mail: ulayspirina@mail.ru

2 - Main Botanical Garden of Russian Academy of Sciences, Botanicheskaya 4, Moscow 127276 Russia Россия 127276 Москва, Ботаническая, 4, Главный ботанический сад PAH, e-mail: misha_ignatov@list.ru 
Fig. 1. Eearly stages of branch development in most pleurocarpus mosses: a schematic summary of Leitgeb (1868) and Berthier (1971).

F1-4 - order of stem leaves; *-branch initial cell, later - apical cell of branch, 1-3 - order of branch leaves.

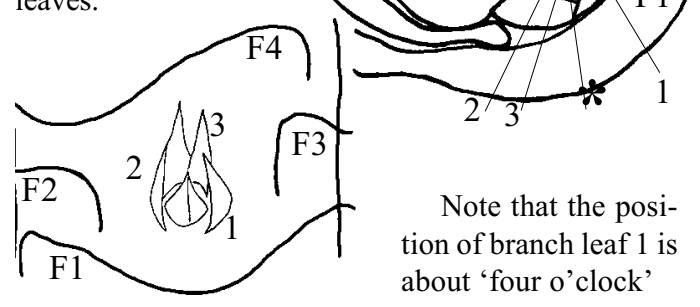

\section{MATERIAL AND METHODS}

\section{Taxa selection}

The study was concentrated on Leucodon, but other genera of the Leucodontaceae were studied as well. Goffinet et al. (2009) include in this family Antitrichia, Dozya, Eoleucodon, Leucodon, Pterogoniadelphus (as Felipponea), Pterogonium and Scabridens. Two of them, Eoleucodon and Scabridens, are rare plants from Polynesia and South China, and they were not included in the present study due to lack of material. Antitrichia, Dozya, and Pterogonium, according to preliminary observations, were found to be quite different from Leucodon and Pterogoniadelphus, thus they are only briefly discussed and not illustrated. Specimen data are given in Appendix 1.

\section{SEM observations}

Branch primordia of Leucodon and Pterogoniadelphus were studied with SEM LEO-430 on shoots from herbarium collections after leaf removal and cover by gold.

\section{Anatomy}

For the anatomy study of Leucodon sciuroides, the stem apical parts of ca. $5 \mathrm{~mm}$ length were isolated, cleared from leaves, and fixed in $4 \%$ glutaraldehyde for 5 days, post-fixed with $1 \%$ osmium tetroxide in Na-phosphate buffer, $\mathrm{pH} 6.8$, for 10 hours. The material was then dehydrated in $70 \%$ ethanol, stained in uranil-acetate (2\% solution in $70 \%$ ethanol for 10 hours), and then dehydrated through a graded ethanol/acetone series to $100 \%$ acetone. After that samples were embedded in araldite 6005 medium, according to the protocol of manufacturer.

Sections were cut $2 \mu \mathrm{m}$ thick with glass knives, and put on glass slides without mounting medium.

Sections were photographed under a Leitz light microscope. However, in contrast with the previously studied species of Hypnum, Brachythecium, etc., the Leucodon sections appeared to have highly refractive material of cell walls, resulting in rather unclear views. Thinner sections of $1 \mu \mathrm{m}$ did not help to obtain better pictures, as well as a number of attempts with a few other specimens of the same species. So in addition to pictures in transmitted light (Figs. 8,9 and in part 5,7 ) we photographed the same sections in a Fluorescent microscope Olympus $\mathrm{C} 41, \lambda=488$, with the berberin staining (cf. Figs. 4, 6, and in parts 5, 7).

The main studied specimen of Leucodon sciuroides was collected in Pskov Province, NW European Russia, in the end of summer. To exclude a possibility of the branch initial structure to differ in times of more active growth, we also studied the anatomy in a number of spring and early summer collections from different regions of European Russia (see Appendix). However, all of them were found to be subidentical to the Pskov specimen (Figs. 2-9) and thus they are not illustrated here.

\section{Cross sections picture presentation}

Note 1. Presented sections are all $2 \mu \mathrm{m}$ thick.

Numbers of pictures correspond to the section numbers and do not always go in order, as some sections in a series are omitted. This allows to understand how many microns are between the shown sections.

Note 2. In case the two types of images, from light and fluorescent microscopy, highlight different details, both of them are presented. Such pictures have the same number, but marked by 'a', e.g. 1 and $1 \mathrm{a}$.

\section{RESULTS}

SEM observation shows that the first branch leaf in Leucodon sciuroides is pointed down- 
ward (Fig. 2: 1-8). Unlike Brachytheciaceae, where the apex of this first leaf is triangular and clearly seen above the bud, the first branch leaves in L. sciuroides are variable. Most buds are almost totally covered by a very big, cucullate leaf (Fig. 2: 2-4), so its upper end is not clearly seen in a light microscope, and in addition in many cases the upper leaf is laciniate or lobate (Fig. 2: $5-8$ ), the lobes being broad to subulate. In exceptional cases a bud may have a big lateral leaf, in a position 'four o'clock' (or 'mirrored four o'clock'), cf. Fig. 3: 1, or very low foliose structure in the same 'four o'clock' position, Fig. 3: 2.

Leucodon pendulus (Fig. 3: 3-5) has a less variable shape of buds. The first branch leaf orientation is the same. In many buds in this species we observed the first branch leaf sometimes reflexed in its lower part (Fig. 3: 3), but shortly above turning to a position similar to other leaves covering dormant bud. The same pattern has been seen in $L$. sciuroides, though infrequently (cf. Fig. 9: 1, 6, 8).

Pterogoniadelphus (Fig. 3: 6-7) is similar to L. pendulus: most of its leaves are triangular and point downwards, although broad lobes are occasionally present (Fig. 3: 6).

Observation on other species of Leucodon under the light microscope showed a principally same pattern. The medium-size species similar to L. sciuroides (L. brachypus, L. immersus, L. coreensis) have first branch leaf at least sometimes split. In slender plants (L. flagellaris), as well as in robust ones (L. dracenae, L. macrosporum, L. sapporense), the first branch leaf is more regularly triangular, similar in this respect to L. pendulus and Pterogoniadelphus.

\section{Anatomy}

Stem apex is quite broadly acute, and its sides form an angle of ca. $90^{\circ}$. Apical cell is ca. $75 \mu \mathrm{m}$ long and $25 \mu \mathrm{m}$ wide. Its shape is elongate ellipsoidal rather than tetrahedral. Leaves are differentiated early: at 10-15 $\mu \mathrm{m}$ from apex leaves are already differentiated as small hillocks (Fig. 4: 1-4).

Branch initial cells are apparent since ca. 30$40 \mu \mathrm{m}$ from the apex, and at the level of its base are represented by at least four cells (Fig. 4: 2-3)

The section subtransversal to branch axis at the stage of differentiation of the third merophyte, ca. $80 \mu \mathrm{m}$ from apex (Fig. 5), shows the standard pattern of the branch initial differentiation, where the first merophyte cell appears in a 'four o'clock position'. The second merophyte cell appears in a lower-lateral position, 'eight o'clock', and the third one is in 'twelve o'clock', although deformation due to pressure from leaves makes these positions inexact. The leaf spiral in pleurocarps can be dextrose or sinestrose, so the position of the first merophyte in 'four o'clock' is mirrored in some shoots into 'eight o'clock' (e.g. in Fig. 5), which however is still called here as 'four o'clock'.

A series of subtransverse sections of branch at a later stage, $100-150 \mathrm{~mm}$ from apex, is presented in Fig. 6 (sections are slightly oblique, as shown in scheme Fig. 6-A).

Since the second youngest merophyte from apical cell (\#9 in Fig. 6: 2), the leaf margins deviate from the branch surface, and since the fifth merophyte (\#6 in Fig. 6) leaf laminae are spaced from neighboring leaves at least at a certain distance.

The outermost leaf with developed leaf lamina is \#3 in Fig. 6, and it is situated in a 'twelve o'clock' position. Cells outside the leaf \#5, corresponding to merophyte $\# 2$, are apparent in some sections (e.g. Fig. 6: 5, 10). Cells corresponding to merophyte \#1 are not always apparent with confidence, because of a somewhat oblique position of sections (cf. Fig. 6-A). However, at least in Fig. 6: 1-2, cells between stem leaf and branch leaf \#4 cannot be interpreted as anything else but merophyte \#1.

Longitudinal section of one branch primordium at ca. $100 \mu \mathrm{m}$ from apex is shown in Fig. 7. At this stage branches have three differentiated merophytes composed by several homogeneous cells each, while the raisings along the sides of apical cell indicate three more merophytes (two of them seen in Fig. 7: 3a). Apical cell is not covered by branch leaves at this stage. The second merophyte (\#2 in Fig. 7: $3 a$ ) does not rise above the stem surface, while the third one (\#3 in Fig. 7: $1 a$ and $3 a$ ) is raised by just half cell, but still higher than the second and first (the latter not shown).

Another series of sections transversal to stem and longitudinal to branch primordia (Fig. 8) shows the stage where the branch has only one leaf that is seen in sections in Fig. 8: 1-4, i.e. 

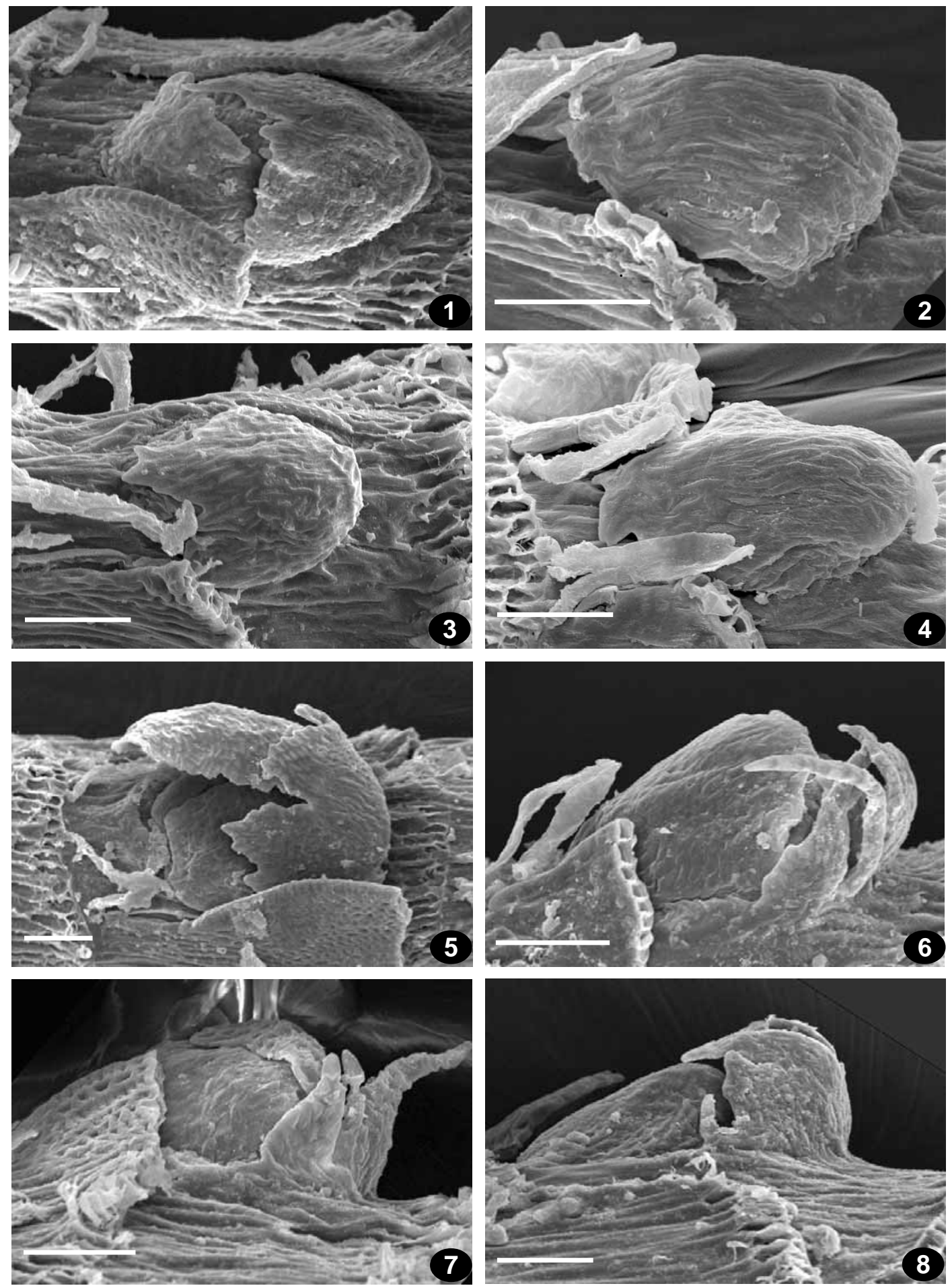

Fig. 2. Branch primordia of Leucodon sciuroides; the outermost developed leaf points downwards, being entire, figs. 1-4, or variously split, figs. 5-8. Scale bar for all pictures $50 \mu \mathrm{m}$. 

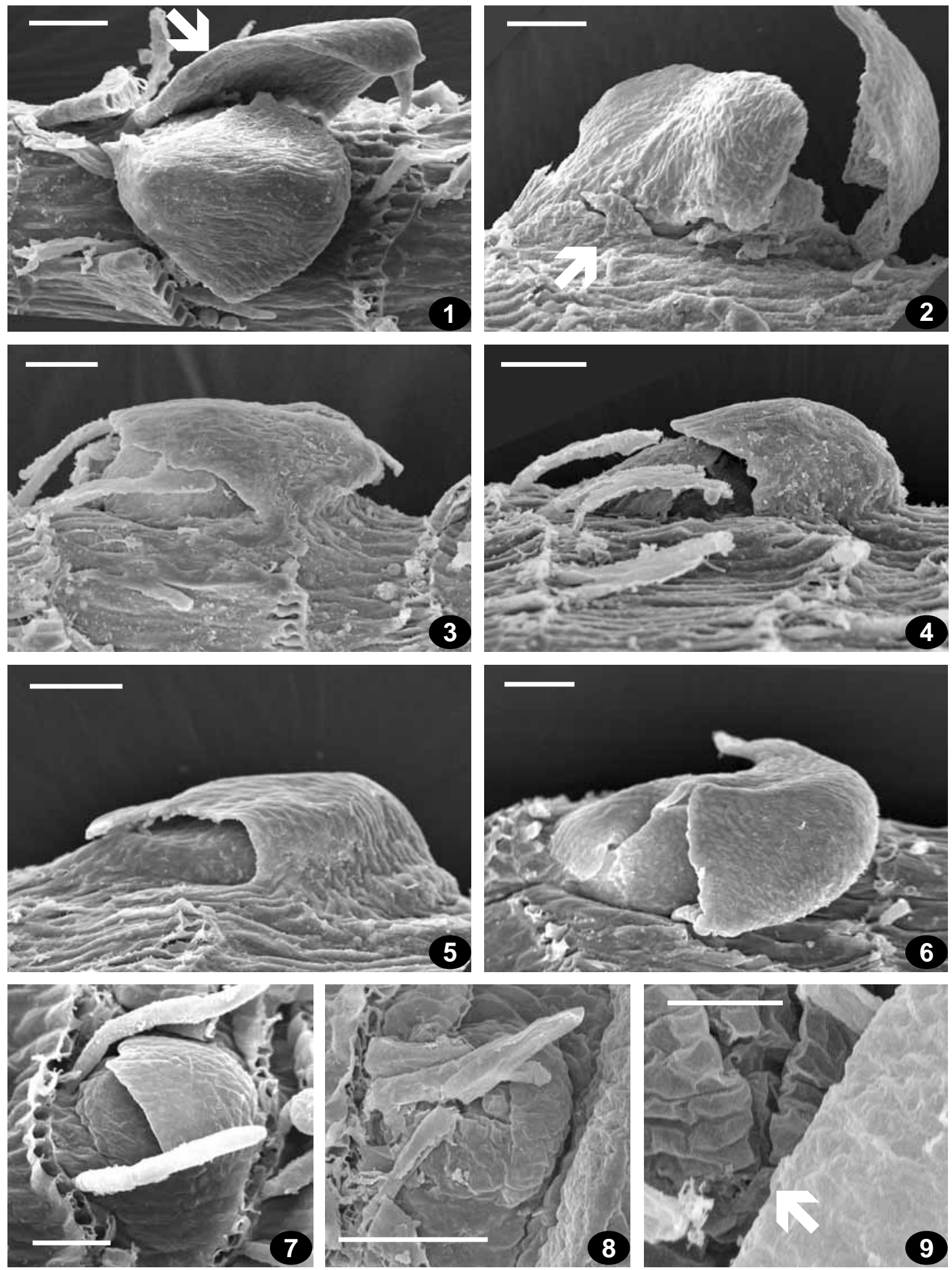

Fig. 3. Branch primordia, showing variation (1-2, 8-9-Leucodon sciuroides; 3-5 - Leucodon pendulus; 67 - Pterogoniadelphus montevidensis). Arrowed: in 1 - well developed lateral leaf corresponding to the first leaf (cf. scheme in Fig. 1, page 96); in 2 - additional foliose structure in 4 o'clock position, corresponging to second leaf (cf. cited scheme); in 9 - the angle of the first developed leaf (corresponding to the third leaf, cf. cited scheme) overlaying the lateral leaf. Scale bars $50 \mu \mathrm{m}$ for 1-8; $20 \mu \mathrm{m}$ for 9 . 

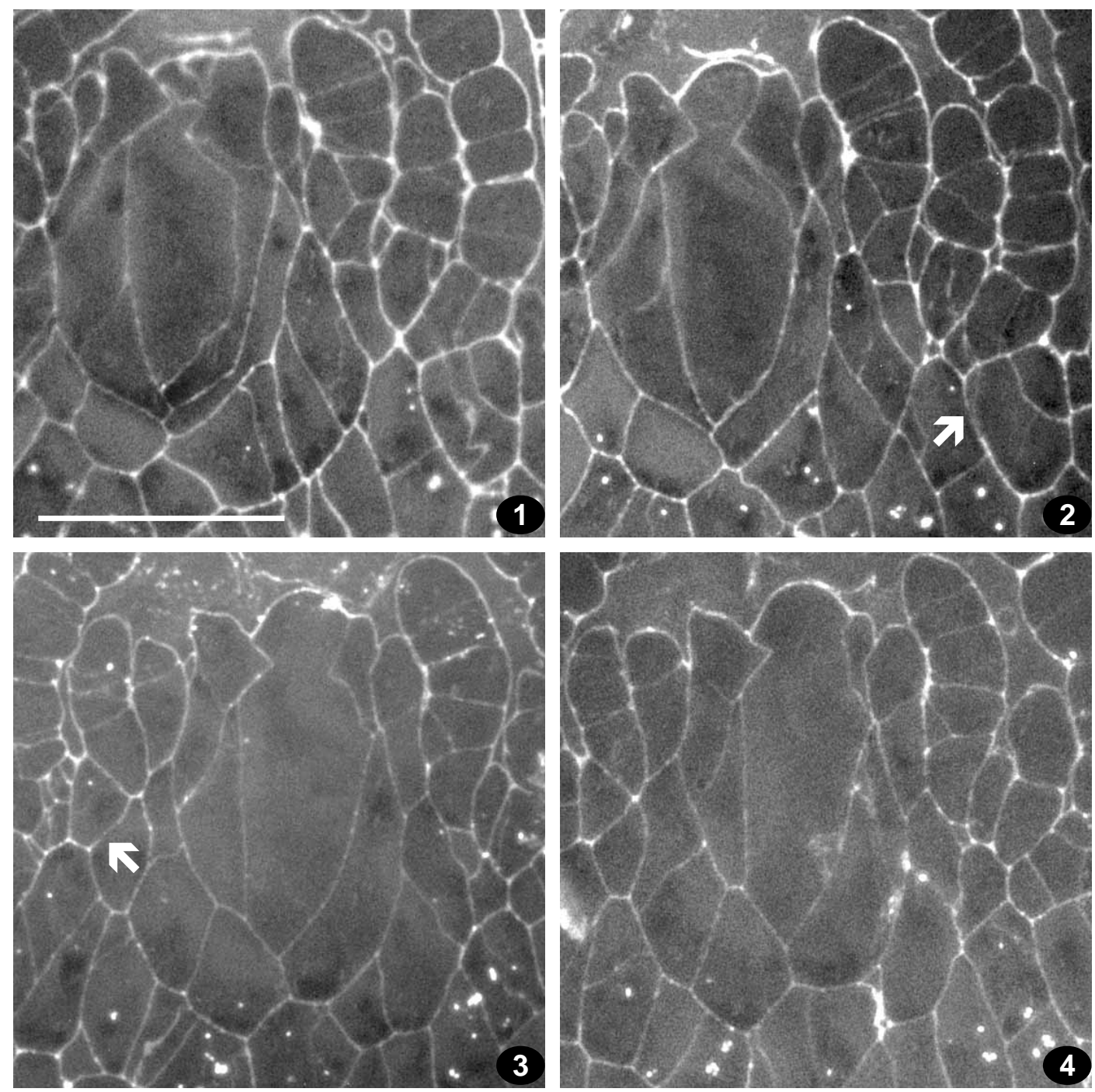

Fig. 4. Longitudinal sections of the stem apical cell of Leucodon sciuroides, scale bar $50 \mu \mathrm{m}$. Arrowed are branch initials / primordia.

Fig. 5. Transmitted light and fluorescent images of subtransverse section of branch primordium of Leucodon sciuroides, at the stage of differentiation of third merophyte. Scale bar $50 \mu \mathrm{m}$. The first merophyte is smaller than the second one due to not exactlty transversal section. Note a rather poor fluorescence of the recently formed cell walls, comparatively with their expression in transmitted light.
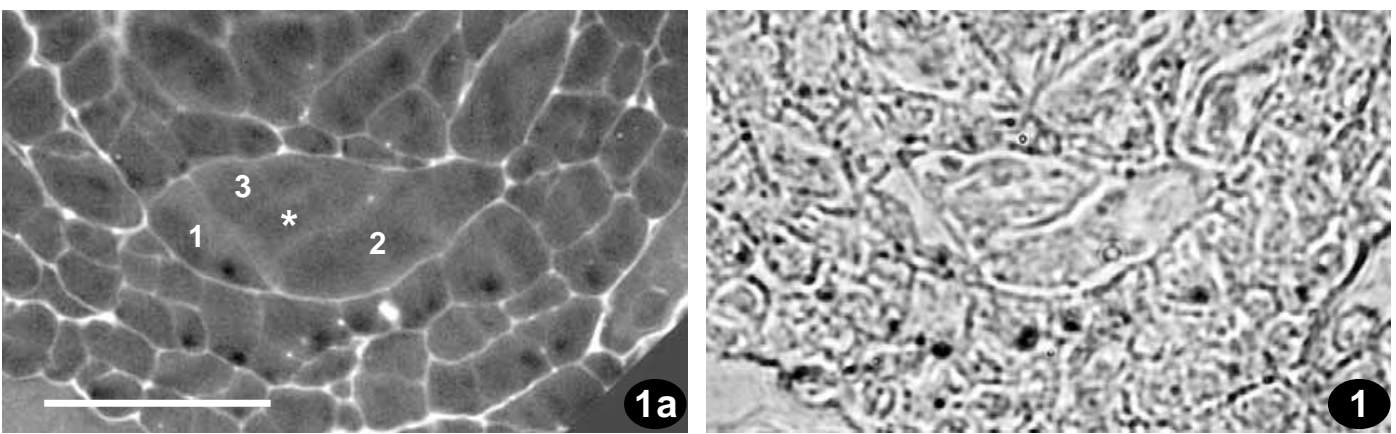

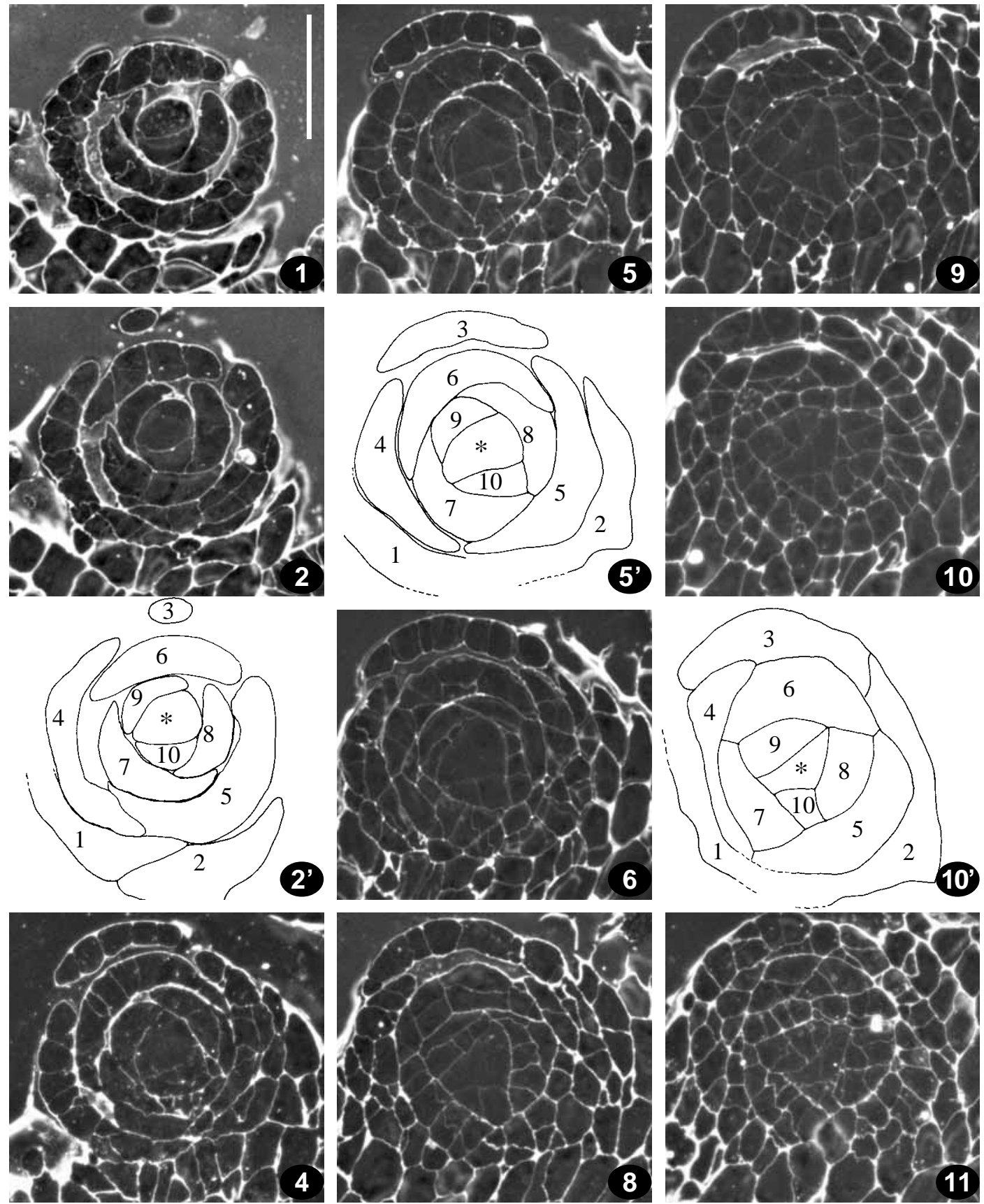

Fig. 6. Subtransversal sections of branch primordium of Leucodon sciuroides at the stage of differentiation of 10th merophyte. 2', 5', 10' schemes show sections with the correspoding numbers. The first developed branch leaf (\#3) occurs in position above the bud along the stem. The second branch merophyte cells (\#2) do not raise above stem surface; they are apparent in 2, 5, 9. Scale bar $50 \mu \mathrm{m}$. The sections are slightly oblique, as shown in scheme A.

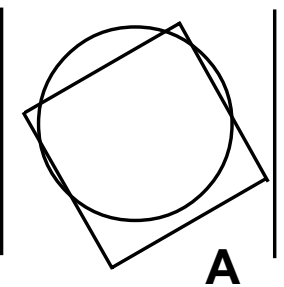



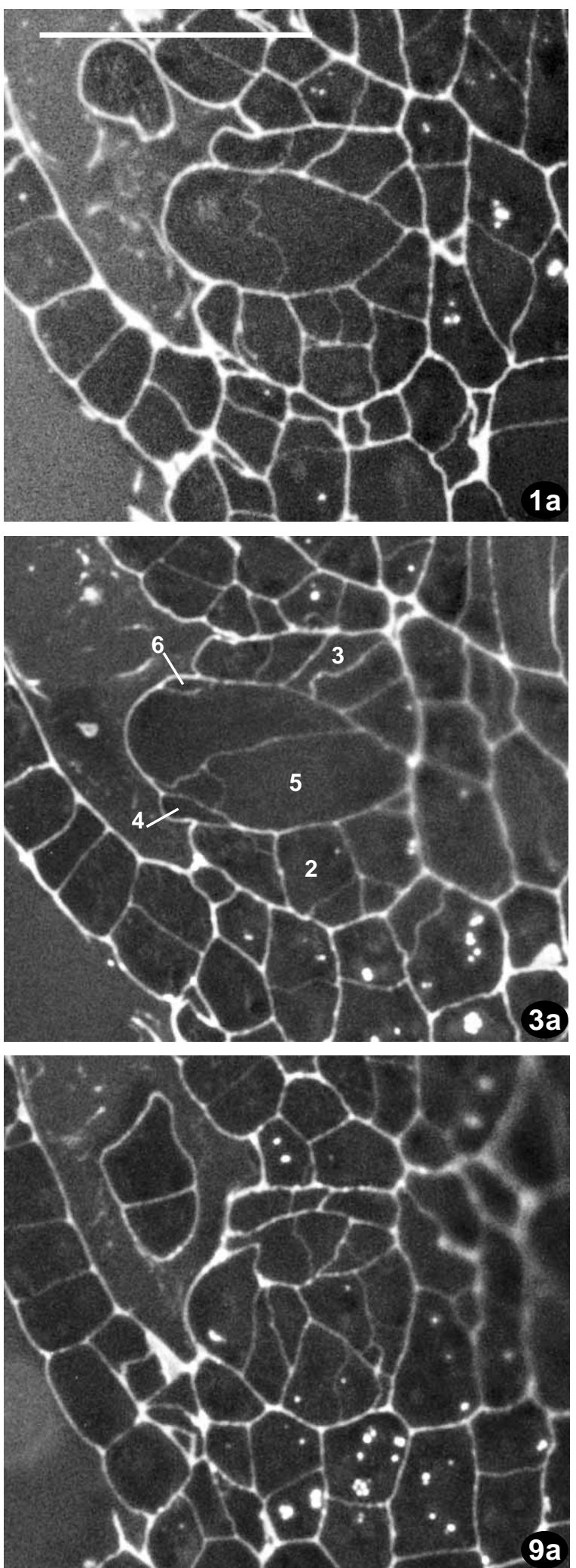

[5. (2) id and

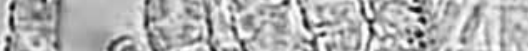
ix (E) 18 Sos

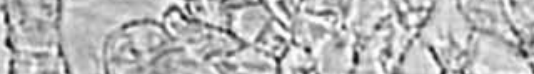

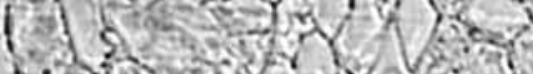

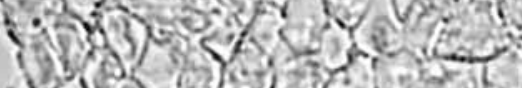

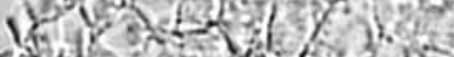
2

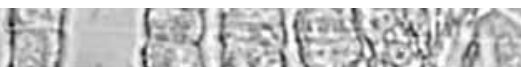
in . kas

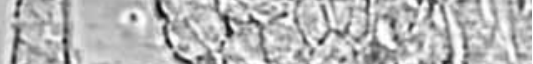

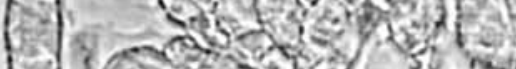

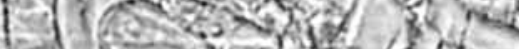

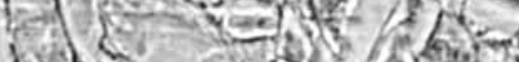

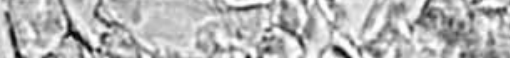

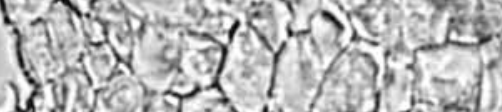
1. Lds

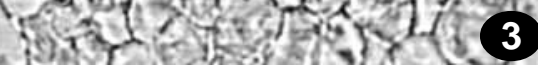

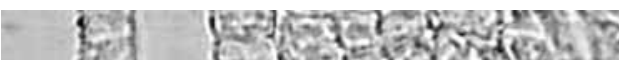
a)

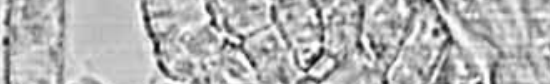

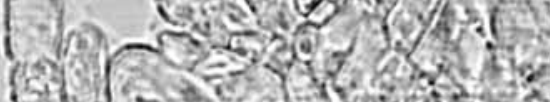

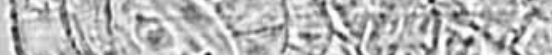

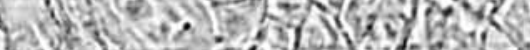

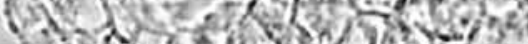

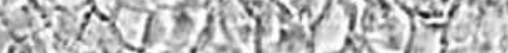

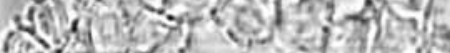

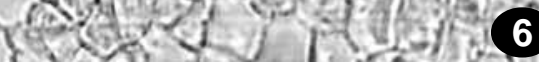

(5) [U, (I) z 7 y

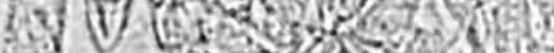
ad 5 -

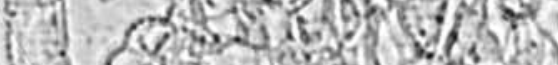

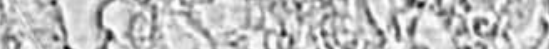

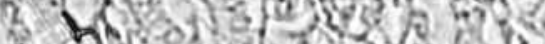

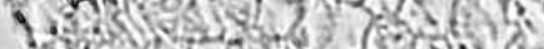
\%. (6) - Do 2 aly 11 

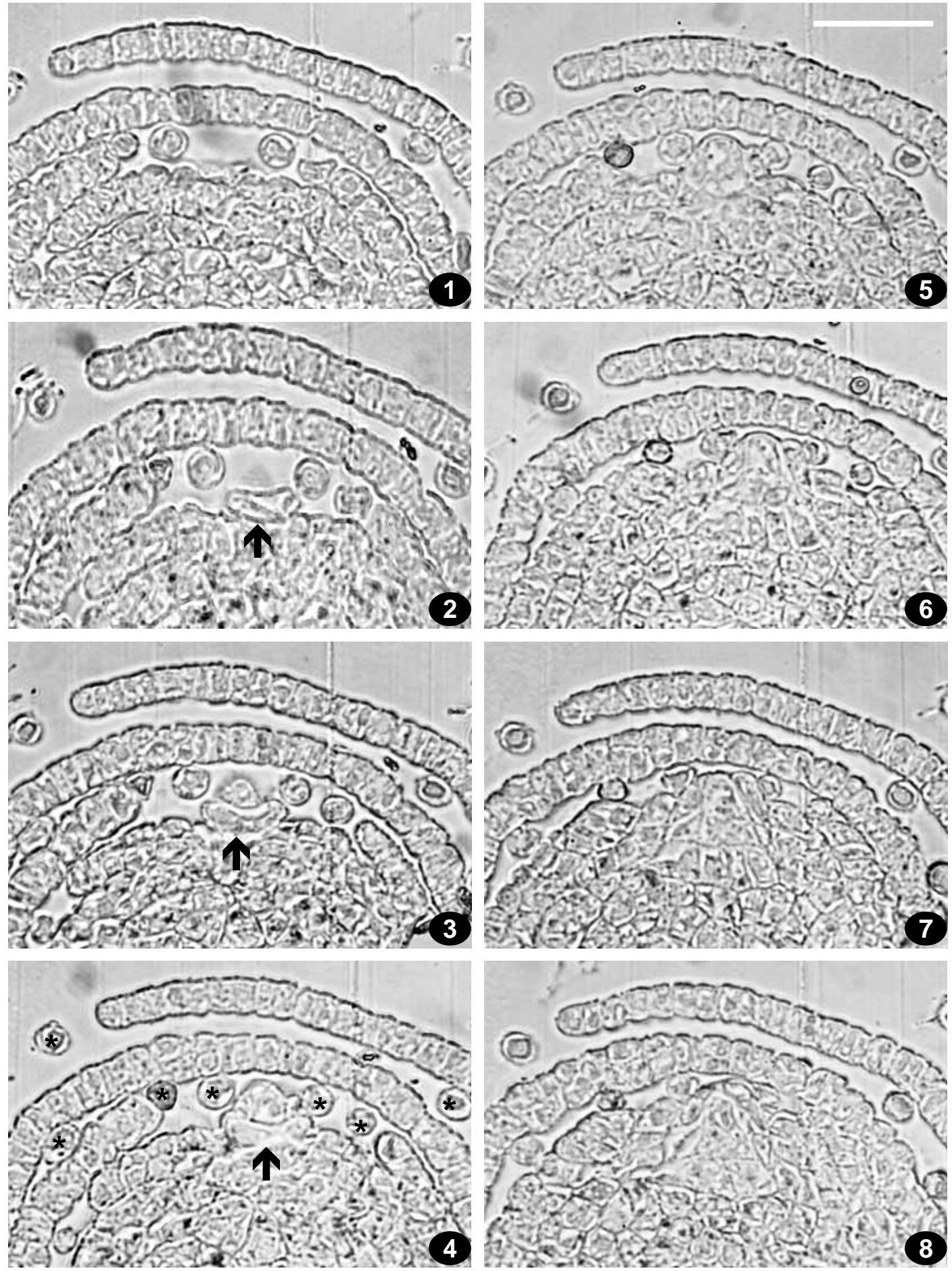

Fig. 8. Series of sections transversal to stem and longitudinal to branch primordium of Leucodon sciuroides at the stage of differentiation of ca. 6th merophyte. The leaf blade is differentiated in only one leaf (arrowed) that is situated above the bud along stem. Scale bar $50 \mu \mathrm{m}$. Axillaxy hairs are marked by asterisk (in 4).

Fig. 7 (opposite page). Longitudinal sections of the branch primordium of Leucodon sciuroides at the stage of differentiation of 6 th merophyte. Scale bar $50 \mu \mathrm{m}$. Merophyte numbers are showin in $3 \mathrm{a}$. 

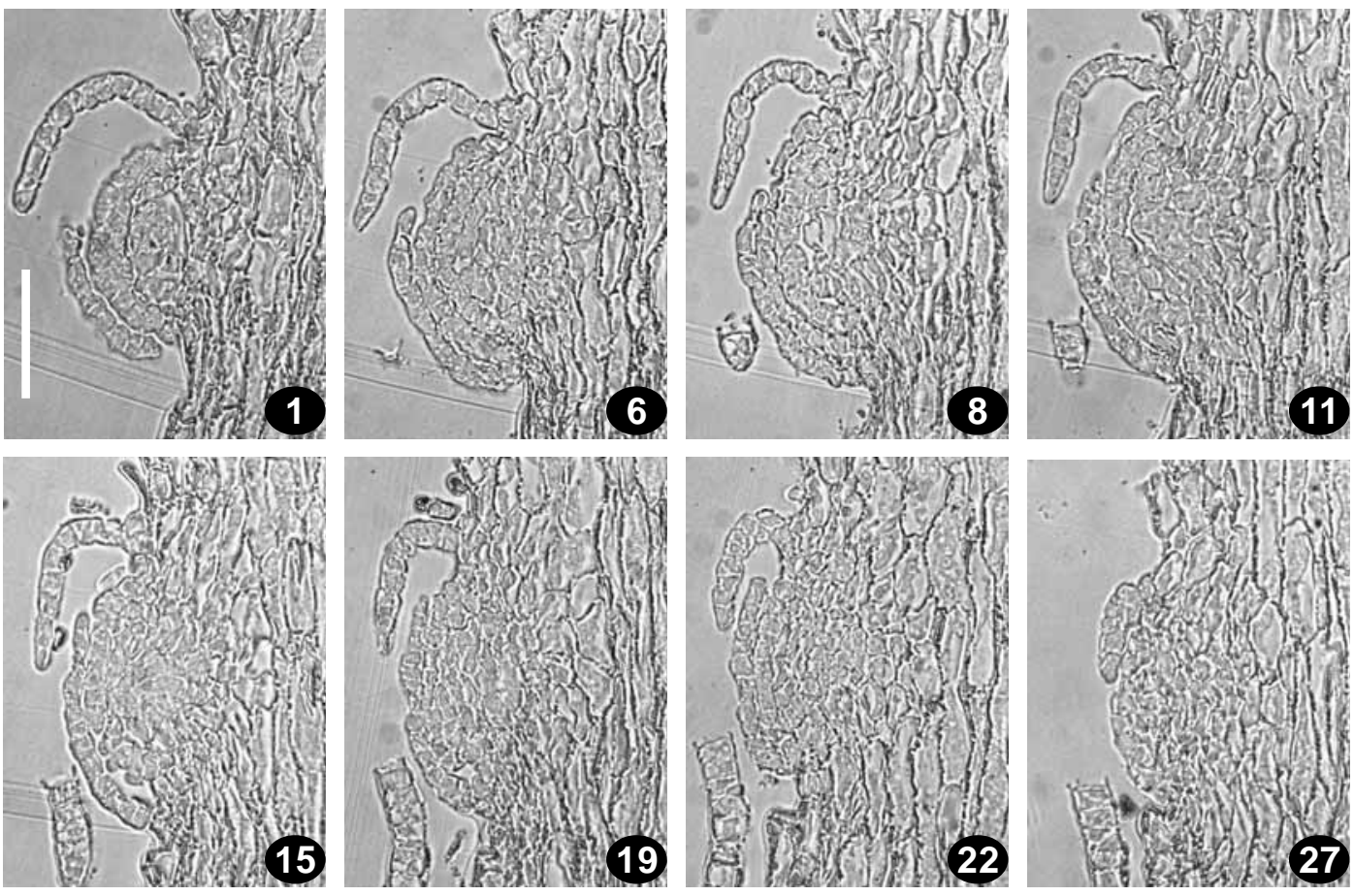

Fig. 9. Longitudinal sections of branch primordium of Leucodon sciuroides (ca. $200 \mu \mathrm{m}$ from apex) showing the reflexed first developed branch leaf (corresponding to third leaf, cf. scheme in Fig. 1, page 140).

closer to stem apex. This leaf is reflexed from its base, which agrees with the shape of this first developed leaf (cf. Figs. 3: 3 and 9). In robust species of Leucodon, e.g. in L. dracaenae (not shown), the first branch leaf in many buds is also often reflexed from base and keeps this direction, because the whole bud has a narrow angle with the stem, being strongly pressed to the latter by stiff erect-appressed leaves.

\section{DISCUSSION}

Obtained results show that the Brachytheciaceae-Meteoriaceae pattern of leaf arrangement around branch primordia is not unique, as has been suggested by Ignatov (1999). At the same time, our previous hypothesis on this pattern being a result of the first two branch leaves reduction (Spirina \& Ignatov, 2005) obtains additional support.

One possible explanation of this reduction can be in epiphytic environments where plants are facing a necessity of very rapid development within a short period of time after being moistened by rain or heavy mist or dew. Buds in Leucodon and Pterogoniadelphus, as well as in Brachythecium start to develop earlier than e.g. in Callier- gon (Spirina \& Ignatov, 2005) or Amblystegium (Spirina \& Ignatov, 2008), so they reach the foliose stage being strongly pressed by surrounding leaves. This pressure may simply preclude the development of lateral leaves. Otherwise, the immediate coverage by decurrencies of nearby leaves (cf. Fig.2: 1) protects the young bud efficiently enough, making some of its own protective structures superfluous.

The Leucodontaceae species are almost all epiphytes, as well as the Meteoriaceae. The Brachytheciaceae include mostly epigeic plants, although many smaller genera (Aerolindigia, Homalotheciella, Remyella, Clasmatodon, etc.) are epiphytes, and within larger genera there are ephyphytic lineages (Brachythecium acuminatum (Hedw.) Austin, Rhynchostegium conostomum (Mont.) Ignatov \& Huttunen, Homalothecium spp., etc.).

Contrary to changes in the sporophyte structure of epiphytes (cf. Huttunen et al., 2004), which seemingly can happen very rapidly in a taxonomic scale of timing, i.e. at the level of species and genera, the 'epiphytic structure of branch primordia' is more conservative, and, as far as we know, is a characteristic of the family level. 
Most Leucodon species are xerophytic plants that grow in places drier that most of the Brachytheciaceae, usually in more southern latitudes, in the environment more suitable for the Meteoriaceae than Brachytheciaceae. This fact may explain a better development of the 'first developed' (e.g. the homologous of the third) branch leaf. The bigger size and cucullate shape (Fig. 2: 2-4) is also known in Meteoriella, Pseudospiridentopsis and some other Meteoriaceae (cf. Ignatov, 1999, Fig. 3A and 3C).

Observation on other species of Leucodon indicates that all of them have a similar structure. A more regular 'Brachytheciaceae \& Meteoriaceae pattern' is observed in either slender plants with distantly arranged leaves, e.g. L. pendulus, L. flagellaris, or otherwise in especially robust species with a larger stem diameter, $L$. dracenae, L. macrosporum, L. sapporense. It seems that in these cases the juvenille branch is less affected by surrounding leaves, comparatively with medium-sized species which more often have a laciniate dissection of the first branch leaf. However, studied material is not enough for any conclusions about details of this leaf splitting.

\section{COMMENTS ON THE VOLUME OF LEUCODONTACEAE}

Observation on Antitrichia, Pterogonium and Dozya, referred to the Leucodontaceae by Goffinet et al. (2009) found the first branch leaf in the 'four o'clock' position in these genera. Molecular phylogenetic data also mostly support the remote position of the two former genera from Leucodon. Antitrichia has been found in a position closer to the Hylocomiaceae than Leucodontaceae by Gardiner et al. (2005) and Ignatov et al. (2007), and the genus was placed in a separate family Antitrichiaceae (Ignatov \& Ignatova, 2004). Tsubota et al. (2004) data are in agreement with its position far from Leucodon.

Pterogonium was resolved in the analysis by Troitsky et al. (2007) in the clade composed mostly by the Lembophyllaceae.

Dozya and Pterogoniadelphus were found in one clade with Leucodon by Tsubota et al. (2004), while the analysis of Cox et al. (2010) found two former genera fairly unrelated, with Leucodon unstudied. The position of Dozya needs further study: superficially this genus is very similar to
Leucodon, but the presence of the costa, specific peristome structure (Akiyama, 1987), and the first branch leaf in a 'four o'clock' position makes it rather distinct from Leucodon.

The genus Alsia was placed in the Leucodontaceae by Frey \& Stech (2009). The first branch leaves are in the lateral position in this genus, which in addition to numerous paraphyllia makes its position close to Leucodon unlikely.

Eoleucodon and Scabridens both have costa, and their placement in Leucodontaceae requires confirmation. Thus, the Leucodontaceae includes definitely only two genera: Leucodon and Pterogoniadelphus.

\section{ACKNOWLEDGEMENTS}

We are grateful to A. Ivanova for correcting English and to A. Babosha for helping with SEM study. The work was partly supported by RFBR 10-04-00678.

\section{LITERATURE CITED}

AKIYAMA, H. 1987. Morphology and anatomy of the peristome of Dozya japonica (Musci) and reconsideration of its affinity to the Leucodontaceae. - Bryologist 90(4): 409-416.

BERTHIER, J. 1971 [1972]. Recherches sur la structure et le développement de l'apex du gamétophyte feuillé des mousses. - Rev. Bryol. Lichénol. 38: 421-551.

COX, C. J, B. GOFFINET, N.J.WICKETT, S.B. DOLES \& A.J.SHAW 2010. Moss diversity: a molecular phylogenetic analysis of genera. - Phytotaxa 9: 175-195.

GARDINER, A., M. IGNATOV, S. HUTTUNEN \& A. TROITSKY 2005. On resurrection of the families Pseudoleskeaceae Schimp. and Pylaisiaceae Schimp. (Musci, Hypnales). - Taxon 54: 651-663.

GOFFINET, B., W. R. BUCK \& A. J. SHAW 2009 [2008]. Morphology, anatomy, and classification of the Bryophyta.In: Goffinet, B. \& A. J. Shaw (eds.) Bryophyte Biology, $2 d$ ed. Cambridge University Press: Cambridge: 55-138.

FREY, W. \& M. STECH 2009. Marchantiophyta, Bryophyta, Anthocerotophyta. - In: Frey, W. (ed.) Syllabus of Plants Families, AdolfEngler's Syllabus derPflanzenfamilien, 13th edition. Part. 3. Berlin \& Stuttgart, Gerbüder Borntraeger Verlagsbuchhandlung: 7-263.

HUTTUNEN, S., M. S. IGNATOV, K. MÜLLER, \& D. QUANDT 2004. Phylogeny and evolution of epiphytism in the three moss families: Meteoriaceae, Brachytheciaceae, and Lembophyllaceae. In: B. Goffinet, V. Hollowell and R. Magill (eds.) Molecular systematics of Bryophytes. Monogr. Syst. Bot. Missouri Bot. Garden 98: 328-361.

IGNATOV, M. S. 1999. Bryophyte flora of the Huon Peninsula, Papua New Guinea. LXIII. On the pseudoparaphyllia in Brachytheciaceae and Meteoriaceae (Musci). - Acta Bot. Fennica 165: 73-83.

IGNATOV, M., A. GARDINER, V. BOBROVA, I. MILYUTI- 
NA, S. HUTTUNEN \& A. TROITSKY 2007. On the relationships of mosses of the order Hypnales, with special reference to taxa traditionally classified in the Leskeaceae. - In: Newton, A.E. \& R. Tangney (eds.), Pleurocarpous mosses. systematics and evolution. CRC Press, Bocan Rota-London-New York: 177-213.

IGNATOV, M. S. \& L. HEDENÄS. 2007. Homologies of stem structures in pleurocarpous mosses, especially of pseudoparaphyllia and similar organs. - In: Newton, A.E. \& R. Tangney (eds.) Pleurocarpous mosses: systematics and evolution. CRC Press, Boca Raton-London-New York (Systematic Association Special Volume 71): 269-286

[IGNATOV, M.S. \& E.A.IGNATOVA] ИГНАTOB M.C., Е.A. ИГНАТОВА 2004. Флора мхов средней части европейской России. Т. 2. - [Moss flora of the Middle European Russia. Vol. 2] M., KMK [Moscow, KMK]: 609-960.

LEITGEB, H. 1868. Wachstum des Stammchens von Fontinalis. - Sitz. d. K. Ak. Wiss. Math. Natur. 57(1): 308-342.
SPIRINA, U. N. \& M. S. IGNATOV 2005. A comparison of early stages of branch development in Brachythecium and Calliergon (Bryophyta). - Arctoa 14: 211-222.

SPIRINA, U. N. \& M. S. IGNATOV 2008. Branch development and pseudoparaphyllia of Hypnum cupressiforme (Hypnales, Musci). - Arctoa 17: 139-160.

TSUBOTA, H., E. DE LUNA, D. GONZALEZ, M.S.IGNATOV \& H. DEGUCHI 2004 [2005]. Molecular phylogenetics and ordinal relationships based on analyses of a large-scale data set of $600 \mathrm{rbcL}$ sequences of mosses. - Hikobia 14: 149-170.

[TROITSKY, A.V., M.S. IGNATOV, V.K. BOBROVA \& I.A. MILYUTINA] ТРОИЦКИЙ, А.В., М.С. ИГНАТОВ, В.К. БОБРОВА, И.А. МИЛЮТИНА 2007. Вклад геносистематики в современное представление о филогении и системе моховидных. - [Contribution of molecular methods to the phylogeny and taxomomy of Bryophyta] Биохимия [Biochemistry] 72(12): 1690-1704.

Appendix 1. Specimens studied (all from MHA)

\section{Anatomy \\ [shown in Figs.2-9]}

Leucodon sciuroides (Hedw.) Schwägr. $\quad$ European Russia, Pskov Province, 16.VIII.2005, Afonina s.n. [not shown in paper]

L. sciuroides European Russia, Orenburg Province, 1.VI.2004, Zolotov \& Spirina

L. sciuroides European Russia, Smolensk Province, 19.VII.2007, Ignatov

L. sciuroides European Russia, Kaluga Province, 20.V.2007, Ignatov \& Teleganova

\section{SEM study}

Leucodon sciuroides

European Russia, 16.VIII.2005, Afonina s.n.

Leucodon pendulus Lindb.

Pterogoniadelphus montevidensis

(Müll. Hal.) M. Fleisch. Brasil, J.-P. Frahm, 1693

\section{Light microscope observations on branch primordia}

First branch leaf in a lateral position

Dozya japonica Sande Lac.

Pterogonium gracile (Hedw.) Sm.

Alsia californica (Hook. \& Arnott) Sull.

Antitrichia curtipendula (Hedw.) Brid.
Russian Far East, Bakalin \#41-25-07

U.S.A., 11.Aug 1989, Ignatov s.n.

U.S.A., 9.Aug 1989, Ignatov s.n.

Russia, 5 May 2005 Ignatov \& Ignatova

\section{First bracnh leaf pointed downwards}

Leucodon brachypus Brid.

Leucodon coreensis Cardot

Leucodon immersus Lindb. ex Broth.

Leucodon sapporense Besch.

Leucodon dracenae Solms et Vent.

Leucodon flagellarus Lindb. ex Broth.

Leucodon julacus (Hedw.) Sull.

Leucodon macrosporus Williams
U.S.A., Glenn Adelson \#054

Russian Far East, Ignatov \#07-501

Russia, Caucasus, Ignatov \& Ignatova \#09-48

Japan 10.IX.1978 Osada \& Muramutsu s.n.

Tanzania, Pocs \& S. Chuwa 88285/AD

Russia, Caucasus, Ignatov \& Ignatova \#05-3564

U.S.A., Vitt \#33710

Panama, Davidse \& D'Arcy \#10206N 